\title{
Garden Strawberry Plants: From Test-Tubes to Plantations
}

\author{
A A Batukaev ${ }^{1}$ and S A Kornatskiy ${ }^{2}$ \\ ${ }^{1}$ Chechen State University, Grozny, Russia \\ ${ }^{2}$ Peoples' Friendship University of Russia, Moscow, Russia
}

\section{Abstract}

The article discusses the role of strawberry in providing people with vitamin products. It emphasizes the direct dependence of productivity of strawberry plants on the quality of the original planting material. A crucial role of clonal micro-propagation was justified. Features of the in vitro propagation stages were identified and new technical solutions for improving production efficiency were offered. The efficiency of auxin-containing paste for adaptation to the peat-based soil substrate was proved. The use of a 2 \% Diazinon solution killed sciaride larvae damaging the roots. Development of an alternative method for adapting microplants to hydroponics made it possible to abandon the use of any substrate and ensure the viability of plants at the level of

Corresponding Author:

A A Batukaev

batukaevmalik@mail.ru

Received: 25 October 2019

Accepted: 15 November 2019

Published: 25 November 2019

Publishing services provided by Knowledge E

(c) A A Batukaev and S A Kornatskiy. This article is distributed under the terms of the Creative Commons

Attribution License, which permits unrestricted use and redistribution provided that the original author and source are credited.

Selection and Peer-review under the responsibility of the AgroSMART 2019 Conference Committee.

\section{G OPEN ACCESS}

95--100\%.

Keywords: strawberries, clonal micropropagation, growth regulators, gormones, microplants, adaptation, gidroponics

\section{Introduction}

The importance of high-quality and safe food is becoming more and more apparent. Fruit and berries play a special role as they are s an irreplaceable source of natural vitamins and many other substances that are beneficial to human health. Thanks to international cooperation, the range of such products in retail chains is growing and the dependence on seasonality of cultivation is decreasing. The situation is characteristic of Russia, although the high price of fresh fruit limit consumption within the required physiological norms.

Among this variety, strawberry is one of the most demanded berries. It is well known for its taste and technological properties. Industrial cultivation techniques have been known for a long time, although technical progress is introducing new elements into this sphere. However, currently, there are few examples of farms with strawberry plantations with an average yield of 10--15 t/ha despite the fact that strawberry can yield more than 20 tons per hectare. It is quite obvious that high-yield strawberry plantations cannot be 
created without the use of high-quality and healthy mother plants. The most justified solution is the use of the original test-tube plants obtained by the in-vitro method. The method of clonal micropropagation developed in the middle of the 20th century was successfully adopted for practical use in relation to a large number of vegetatively propagated plants, including strawberry [1--4]. Garden strawberry was a model plant used for implementing methodological issues. During clonal micropropagation, the main specific stages were identified which was useful in studying other plant species. However, despite the extensive experience, works on strawberry production are still relevant [5--6]. First, the short life span of the mother plantations requires large-scale production of test-tube plants for their renewal. Second, there are new varieties of an intensive type that require specific approaches. Third, there is an in vitro stage that is the most time consuming and costly. This is the stage of adaptation of test-tube plants to non-sterile conditions, when large losses of material are possible due to the negative impact of a number of factors (light, temperature, air and soil humidity, infectious).

\section{Materials and Methods}

The purpose of the research is to study peculiarities of the technological adaptation of the in vitro method for large-scale micropropagation of strawberry focused on systemic renewal of mother plants. The studies were carried out in the biotechnological laboratory of the Peoples' Friendship University of Russia in 2013--2018. The research objects were modern and highly productive varieties of strawberry of foreign selection: Kimberley, Asia, Florence, Darselect. During the micropropagation, basic elements of the in vitro technology were used. They were partially modernized taking into account varietal specificity. The initial material used was the tops of the stolons obtained at the end of the season. The material was being washed using tap water for one hour; the surface was being sterilized with silver nitrate $\left(\mathrm{AgNO}_{3}\right)$ at a concentration of $1 \%$ for eight minutes. The nutrient medium for the stages of introduction into culture, proliferation of explants, elongation of shoots and rooting of micro rosettes was prepared according to the Murasige-Skoog recipe [9]. In the first three cases, benzylaminopurine (6-BAP) at concentrations of $0.1 \mathrm{mg} \mathrm{L-1}, 1.0 \mathrm{mg} \mathrm{L-1}$ and $0.05 \mathrm{mg} \mathrm{L-1}$, was used as a growth regulator. For transplantation into the nutrient medium, explants were divided into parts consisting of 3--4 micro-shoots. At the stage of rhizogenesis, instead of cytokinin, indole acetic acid ( $\beta$-IAA) at a concentration of $1.0 \mathrm{mg} \mathrm{L-1}$ or a completely hormone-free medium were used. One micro-outlet was planted into each tube; for each variant, 40 tubes were used. The share of rooted micro rosettes, the number and length of roots were recorded 
one month after planting. At the adaptation stage, methods for transplanting microplants from sterile to non-sterile conditions were compared. The traditional scheme of planting micro-plants into the substrate was used for control. The neutralized high-moor peat Agrobalt was used as a substrate. The substrate was subjected to heat treatment in the autoclave at a temperature of $125{ }^{\circ} \mathrm{C}$ for two hours. Before planting, the roots of the microplants were dipped into the paste consisting of opowdered chalk (6.5\%), water (33\%), $2 \%$ insecticide Pochin (Diazinon) and $0.05 \%$ indolylbutyric acid.

To adapt microplants to hydroponics, plastic pallets $50 \times 30 \times 4(\mathrm{~L} \times \mathrm{W} \times \mathrm{H}) \mathrm{cm}$ in size were used. On their surface, light nonwoven spunbond material with a density of $17--30 \mathrm{~g} / \mathrm{m}^{2}$ was fixed. Spunbond was perforated according to the chosen landing pattern $3.5 \times 3.5 \mathrm{~cm}$. Micro-plants were removed from the tubes, prepared for planting by washing the root system from the agar nutrient medium. Planting was carried out through the holes using tweezers, after which the trays were filled with a solution of mineral salts based on the composition of the Murashige-Skoog medium. Circulation of the solution was controlled using a daily time switch. In each variant, 100 microplants were planted. A 16-hour photoperiod was maintained, illumination was 5--6 thousand luxes at the surface level of the vessels and plants, the temperature was $+20 \ldots+22{ }^{\circ} \mathrm{C}$ for the in vitro material and $+22 \ldots+24{ }^{\circ} \mathrm{C}$ for adaptation of microplants. The differences were evaluated using the LSD test at a significance level of $5 \%$ [10].

\section{Results and Discussion}

Introduction showed the survival rate of the material in the range of $50--80 \%$. In this period, careful rejection of plants with the slightest visual signs of bacterial infection was extremely important. At the proliferation stage, this procedure was carried out monthly and systematically, and, moreover, plants with emerging signs of vitrification were completely excluded from the subsequent reproduction. Compliance with these regulations as well as transplantation terms within 3--4 weeks allowed us to stabilize and ensure the high level of proliferation. The average reproduction rate ranged from 4--5 for Florence and Darselect to 5--6 for Kimberley and Asia. At the moment, these varieties are in the stage of active and continuous reproduction since 2013 and have not manifested any obvious problems, besides the variety-specific ones. Asia has proved to be the most stable. Other varieties were prone to vitrification by $8--12 \%$ per passage, especially Kimberley vitrified by $80--90 \%$ at a temperature over $+24^{\circ} \mathrm{C}$. The temperature of $+180{ }^{\circ} \mathrm{C}$ reduced this effect to $0--3 \%$. In all varieties, except for Florence, very dense conglomerates were formed within 1 month, which, if the terms of the transplantation 
were not observed, sharply reduced viability. The summarized data on reproduction coefficients are presented in Table 1.

TABLE 1: Average values of reproduction coefficients by years.

$\begin{aligned} & \text { Average values of } \\ & \text { reproduction coefficients } \\ & \text { by years* Variety }\end{aligned}$
Asia
Darselect
Florence
Kimberly

Average

\begin{tabular}{|l|l|}
\hline 2014 & 2015 \\
\hline 5.5 & 5.7 \\
\hline 4.4 & 4.2 \\
\hline 3.6 & 3.9 \\
\hline 4.7 & 4.2 \\
\hline 4.6 & 4.5 \\
\hline
\end{tabular}

\begin{tabular}{|l|}
\hline 2016 \\
\hline 5.7 \\
\hline 4.4 \\
\hline 3.7 \\
\hline 4.3 \\
\hline 4.5 \\
\hline
\end{tabular}

\begin{tabular}{|l|}
\hline 2017 \\
\hline 6.1 \\
\hline 4.6 \\
\hline 4.1 \\
\hline 5.1 \\
\hline 4.9 \\
\hline
\end{tabular}

\begin{tabular}{|c|c|}
\hline 2018 & Average \\
\hline 6.0 & 5.7 \\
\hline 4.1 & 4.3 \\
\hline 4.3 & 3.9 \\
\hline 4.9 & 4.6 \\
\hline 4.7 & $\mathrm{HCP}_{05}=1.4$ \\
\hline
\end{tabular}

* -- average annual values from 10--11 passages.

Elongation is a critical stage in the micropropagation of strawberry. While Asia and Florence formed from 8 to 20 micro-rosettes $3--5 \mathrm{~cm}$ in height per 1 cultivation vessel, Kimberly and Darselect had signs of strong vitrification. Excessive optimal cultivation time (1 month) caused the death of explants due to intoxication with waste products. However, this negative effect was eliminated when the cultivation vessels (flasks) were placed so that the temperature in the basal part of the conglomerates was $4--5^{\circ} \mathrm{C}$ lower than the terminal one. The opposite effect takes place in the shelf light room, when the lamps of the lower tier heat up the shelf located above. In our case, the elimination of this factor allowed us to extend the resource of the nutrient medium up to 1.5 months and obtain micro-rosettes of the required quality in problem varieties. As a result of the additional analysis of this problem, it was suggested studying peculiarities of gas exchange between the internal volume of the cultivation vessel and the environment, since dense sealing of Kimberley and Florence with a polymeric film aggravated the vitrification and caused the death of the plants. The use of polyvinyl chloride film instead of polyethylene one confirmed our assumption about possible negative effects of ethylene. It could accumulate inside the cultivation vessels and cause vitrification [12].

As our earlier studies showed, active root formation occurs at the elongation stage. This indicates that endogenous auxin synthesis is characteristic of in vitro plants. In this regard, the need for exogenous auxins is low. As can be seen from Table 2, the presence of auxins in the nutrient medium accelerated root formation by 5--7 days in comparison with the hormone-free medium and contributed to formation of a larger number of roots, but the root growth was relatively weak. And, on the contrary, rapid root growth and a small number of formed roots were observed in the non-hormonal 
medium. The percentage of rooting was lower, but the situation leveled out with an increase in the rooting period. Without the use of hormones, an increase in the duration of the contact of plants with the medium did not have negative effects; the developing roots had normal structures. At the same time, a longer contact of the roots with auxin caused degeneration of their structure due to an increase in the callus mass in the root zone. There were no differences in the rooting rate of micro-rosettes depending on the concentration of the mineral base of the nutrient medium which speaks for the fact that $1 / 2$ of the salt concentration is sufficient for rhizogenesis of strawberry plants.

Although the intensity of root growth and their total length differed quite significantly in different variants, this was crucial for the process of adaptation to non-sterile conditions during mass planting for the successful survival of microplants. According to our observations, general physiological parameters of micro-plants, i.e. specific sizes of plants and phases of their development are important.

Since clonal microproduction of strawberries is usually carried out during the calendar year, the final stage of adaptation of microplants can be carried out in various lighttemperature conditions. Shelving sheds, phytotrons, greenhouses can be used [13--14]. For mass planting, the level of preventive phytosanitary measures in the process of adaptation of microplants turns out to be even more important, which determines their viability, especially at the beginning of the procedure. The main focus of phytosanitary measures was the fight against sciarides which increased in their number while expanding the volume of material in the adaptation light room. Larvae destroyed the roots of the plants which caused their deaths or severe growth retardation. The similar problem is characteristic of the mushroom industry, greenhouse farming, etc. The roots of our plants lack protective covers. They are supersaturated with carbohydrates, that is, they are ideal food for insect larvae. The second problem is a very spread of pathogenic fungi. This required the use of fungicides, but the number of dead plants was significant (Table 3). We developed a scheme for adaptation of microplants that does not require the substrate. Under hydroponic conditions, the stem part was in a humid chamber, while the roots developed in the circulating solution of mineral salts, which made it possible to ensure a high viability rate contributed to adaptation (Table 3, Fig. 1).

\section{Conclusion}

As practice has shown, not always, already known experience turns out to be useful, especially for large-scale. There are problems requiring situational solutions. Development of the most efficient technology is extremely important for synchronization of 
TABLE 2: Rhyzogenesis Of Strawberry Varieties Depending On The Composition Of The Nutrient Medium Used For Rooting.

\begin{tabular}{|c|c|c|c|c|}
\hline \multirow{2}{*}{$\begin{array}{l}\text { Nutrient medium } \\
\text { for rhizogenesis }\end{array}$} & \multicolumn{4}{|c|}{ Rooting rates } \\
\hline & $\begin{array}{l}\text { Beginning of the } \\
\text { rooting process } \\
\text { after planting, } \\
\text { days }\end{array}$ & $\begin{array}{l}\text { Rooting one } \\
\text { month after } \\
\text { planting, \% }\end{array}$ & Number of roots & $\begin{array}{c}\text { Length of roots, } \\
\text { see } \mathrm{cm}\end{array}$ \\
\hline \multicolumn{5}{|c|}{ Asia } \\
\hline IA $1,0 \mathrm{mg} / \mathrm{I}$ & 6.7 & 100 & 6.2 & 3.4 \\
\hline $1 / 2$ IA $1,0 \mathrm{mg} / \mathrm{I}$ & 7.3 & 100 & 5.5 & 4.1 \\
\hline $\begin{array}{l}\text { Hormone-free } \\
\text { medium }\end{array}$ & 14.1 & 85.8 & 2.4 & 5.2 \\
\hline $1 / 2$ IA $1,0 \mathrm{mg} / \mathrm{I}$ & 14.5 & 91.1 & 2.3 & 6.1 \\
\hline \multicolumn{5}{|c|}{ Darselect } \\
\hline IA $1,0 \mathrm{mg} / \mathrm{I}$ & 6.8 & 100 & 4.9 & 2.9 \\
\hline $1 / 2$ IA $1,0 \mathrm{mg} / \mathrm{I}$ & 6.9 & 100 & 5.1 & 2.8 \\
\hline $\begin{array}{l}\text { Hormone-free } \\
\text { medium }\end{array}$ & 13.9 & 87.5 & 1.9 & 5.7 \\
\hline $\begin{array}{l}1 / 2 \text { МС 6ез } \\
\text { гормоноВ }\end{array}$ & 13.8 & 85.0 & 2.1 & 5.6 \\
\hline \multicolumn{5}{|c|}{ Florence } \\
\hline IA $1,0 \mathrm{mg} / \textrm{ }$ & 7.0 & 100 & 4.5 & 3.1 \\
\hline $1 / 2$ IA $1,0 \mathrm{mg} / \mid$ & 7.1 & 100 & 4.8 & 3.3 \\
\hline $\begin{array}{l}\text { Hormone-free } \\
\text { medium }\end{array}$ & 12.9 & 100 & 2.3 & 6.1 \\
\hline $1 / 2$ IA $1,0 \mathrm{mg} / \mathrm{I}$ & 13.1 & 100 & 2.4 & 6.4 \\
\hline \multicolumn{5}{|c|}{ Kimberly } \\
\hline IA $1,0 \mathrm{mg} / \mathrm{I}$ & 7.1 & 100 & 5.4 & 3.0 \\
\hline $1 / 2$ IA $1,0 \mathrm{mg} / /$ & 7.3 & 100 & 5.6 & 3.1 \\
\hline $\begin{array}{l}\text { Hormone-free } \\
\text { medium }\end{array}$ & 13.9 & 67.5 & 2.6 & 5.1 \\
\hline $1 / 2$ IA $1,0 \mathrm{mg} / \mid$ & 14.3 & 75.0 & 2.3 & 5.7 \\
\hline $\mathrm{HCP}_{05}$ & & & 1.9 & 2.1 \\
\hline
\end{tabular}

works whose main link is an in vitro plant. The most vulnerable element of the in vitro technology is adaptation to non-sterile conditions, when it is very difficult to control a large number of factors. The new method for adapting microplants to hydroponics decreases the number of dead plants produced in vitro. This material can be grown to the parameters that allow to plant it into the substrate. In addition, the method for 
TABLE 3: Comparison Of Efficiency Of Different Schemes For Adaptation Of Micro-Plants To Non-Sterile Conditions.

\begin{tabular}{|c|c|c|c|c|}
\hline \multirow[t]{3}{*}{ Variety } & \multicolumn{4}{|c|}{ Adaptation schemes } \\
\hline & \multicolumn{2}{|c|}{ Traditional, using substrate } & \multicolumn{2}{|c|}{ Hydroponics, without substrate } \\
\hline & $\begin{array}{c}\text { Plant survival rate } \\
\text { during adaptation, } \\
\%\end{array}$ & $\begin{array}{l}\text { Plant survival } \\
\text { when } \\
\text { transplanted into } \\
\text { the substrate, \% }\end{array}$ & $\begin{array}{c}\text { Plant survival } \\
\text { during adaptation, } \\
\%\end{array}$ & $\begin{array}{l}\text { Plant survival } \\
\text { when } \\
\text { transplanted into } \\
\text { the substrate, \% }\end{array}$ \\
\hline Asia & 85.0 & 100.0 & 100.0 & 95.0 \\
\hline Darselect & 71.0 & 100.0 & 98.0 & 91.8 \\
\hline Florence & 90.0 & 100.0 & 100.0 & 100.0 \\
\hline Kimberly & 76.0 & 94.7 & 95.0 & 86.3 \\
\hline
\end{tabular}

adapting strawberry microplants to hydroponics can be used for other herbs with a similar stem structure (e.g., pineapple and banana).

\section{Acknowledgment}

The research was financially supported by the Ministry of Science and Education of the Russian Federation as part of the Federal Target Program "Research and development in priority areas of development of the scientific and technological complex of Russia for 2014-2020." (Agreement No. 14.577.21.0292 of 04.12.2018) with a unique project identifier RFMEFI57718X0292

\section{References}

[1] Bhatt, I.D., Dhar, U. (2000). Micropropagation of Indian wild Strawberry. Plant Cell. Tiss. Organ Cult., vol. 60, pp. 83--88.

[2] Sakila, S., Ahmed, M.B., Roy, U.K., Biswas, M.K., Karim, R., Razvy, M.A., Hossain, M., Islam, R., Hoque, A. (2007). Micropropagation of Strawberry (Fragaria $X$ ananassa Duch.) A Newly Introduced Crop in Bangladesh. American-Eurasian Journal of Scientific Research, no. 2(2), pp. 151--154.

[3] Hasan, M.N., Nigar, S., Rabbi, M.A.K., Mizan, S.B., Rahman, M.S. (2010). Micropropagation of strawberry (Fragaria x ananassa Duch.). Int. J. Sustain. Crop Prod., vol. 5(4), pp. 36--41.

[4] Rattanpal, H.S., Gill, M.I.S., Sangwan, A.K. (2011). Micropropagation of strawberry through meristem culture. Acta horticulturae, vol. 890, pp. 149--153. 
[5] Moisander, J., Herrington, M. (2006). Effect of micro-propagation on the health status of strawberry planting material for commercial production of strawberry runners for Queensland. Acta horticulturae, vol. 708, pp. 271--273.

[6] Hochmuth, G., Cantliff, D., Chandler, C., Stanley, C., Bish, E., Waldo, E., Legard, D., Duval, J. (2006). Containerized strawberry transplants reduce establishment--period water use and enhance early growth and flowering compared with bare-root plants. Hortchnology, vol. 16, pp. 46--54.

[7] Chien-Ying, K., Al-Abdulkarim, A.M., Al-Jowid, S.M., Al-Baiz, A. (2009). An effective disinfection protocol for plant regeneration from shoot tip cultures of strawberry. African Journal of Biotechnology, vol. 8(11), pp. 2611--2615.

[8] Munir, M., Iqbal, S., Baloch, J.U.D., Khakwani, A.A. (2015). In vitro explant sterilization and bud initiation studies of four strawberry cultivars. Journal of Applied Horticulture, vol. 17(3), pp. 192--198.

[9] Murashige, T., Skoog, F. (1962). A revised medium for rapid growth and bioassays with tobacco tissue culture. Physiol. Plant., vol. 15(3), pp. 473--479.

[10] Steel, R.G.D., Torrie, J.H. (1980). Principle of statistics. A biometrical approach, 2nd. McGraw-Hill Kogakusha (Ltd), 245 p.

[11] Haddadi, F., Aziz, M.A., Saleh, G., Rashid, A.A., Kamaladini, H. (2010). Micropropagation of strawberry cv. Camarosa: Prolific shoot regeneration from in vitro shoot tips using Thidiazuron with N6-benzylamino-purine. Hort Science, vol. 45, pp. 453--456.

[12] Hdider, C., Desjardins, Y. (1993). Prevention of shoot vitrification of strawberry micropropagated shoots proliferated on liquid media by new antivitrifying agents. Can. J. Plant Sci., vol. 73, pp. 231--238.

[13] Litwińczuk, W., Zubel A. (2005). Growth in vitro cultures of strawberry (Fragaria $\times$ ananassa Duch.) depending on different photoperiods. Folia Horticulturae, vol. 17/2, pp. 81--87.

[14] Biswas, M.K., Hossain, M., Ahmed, M.B., Roy, U.K., Karim, R., Razvy, M.A., Salahin, M., Islam, R. 2007. Multiple Shoots Regeneration of Strawberry under Various Colour Illuminations. American-Eurasian Journal of Scientific Research, vol. 2, pp. 133--135. 